\title{
First Report on Saskatchewan Falconry Association Banding Program
}

\author{
by Glen A. Fox, Kindersley
}

It would seem appropriate, after pleas for assistance and co-operation in our banding program, that the Saskatchewan Falconry Association should publish a preliminary report.

The author has been banding for the Association since 1960. During 1960 I banded on a sub-permit under Dr. Stuart Houston. In 1961 I was granted a permit of my own. In 1962 Spencer G. Sealy was also granted a permit, and rather late in the season, three other members of the Association were granted sub-permits under me.

As you well know, raptors do not nest in large numbers in easily accessible places, but rather in varied habitats over a vast area, different parts of which vary in accessibility. Many hours have been spent in the field searching for nests and in the banding of nestlings as well as in efforts to road-trap adults. I feel that 7,000 miles is a conservative estimate of the Association's travels, the expenses of which have all been defrayed by the members. Rain and the resulting mud have caused many memorable but grueling experiences. However, it is our feeling that the results have certainly justified the effort, and will continue to do so.

Our field methods are improving constantly. We are perfecting new trapping techniques. An elaborate filing system has been established which will contain detailed reports on each nest and each adult bird banded, and any other notes on raptors observed in the field. These records will be used, when sufficient are available for a significant sample, in studies of all aspects of the life history of the raptors. We now collect blood samples from all individuals for virus and disease studies being carried out by Dr. R. Connell of the Veterinary Science Dept. of the University of Saskatchewan, Saskatoon.

Below is a list of all bandings carried out under my supervision as director of the banding program. Banding under the supervision of the Saskatchewan Museum of Natural History is not included. Snowy Owl bandings will be reported elsewhere.

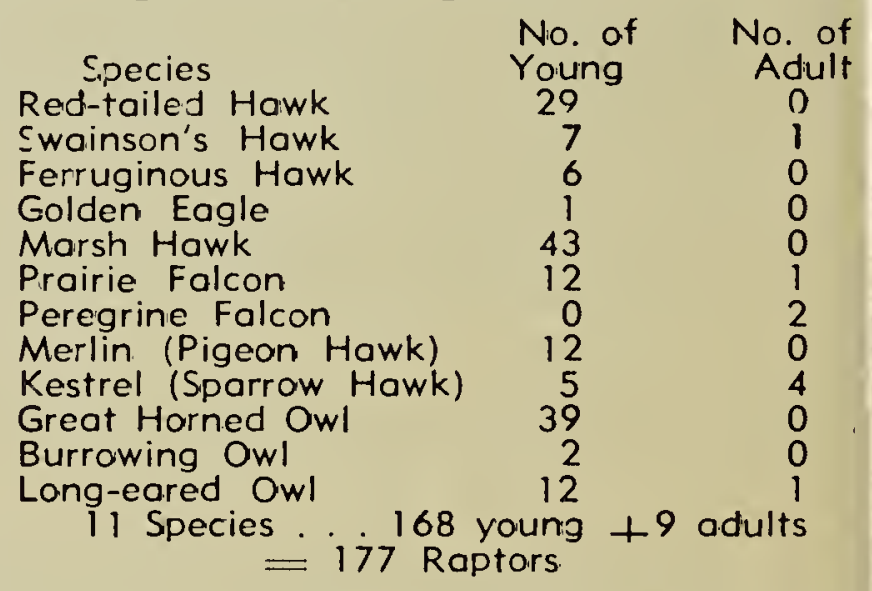

Grateful acknowledgment is made to the following: Canadian Wildlife Service, Sask. Dept. of Natural Resources, Dr. Stuart Houston, Spencer G. Sealy, Gary Anweiler, and all members of the S.N.H.S. who have suppported us and all members of the Saskatchewan Falconry Association who have given of their time and talents in the field to make this project possible.

\section{Fifth Annual Report of the Prairie Nest Records Scheme}

\author{
by Elmer L. Fox, Regina
}

Statistics compiled for our five years of operation reveal that well over 5,000 cards have been turned in recording breeding information on 208 species of birds in the Prairie Provinces and the territory to the north. In 1962, 28 contributors for- warded 561 cards on 129 species. Relatively speaking, the number of cards submitted was rather small. A number of our regular contributors have so far (January 15) not sent in their returns. We earnestly request that they do so immediately as the 
information they contain is important.

The returns for 1962 were remarkable in many respects. Evidence of breeding for ten new species was recorded. W. H. Burns of Leduc, Alberta, added six new species to the list: he submitted information on over 50 nests. Of particular interest to Saskatchewan readers is his report from Alberta of the nest of the Townsend's Solitaire. This fascinating bird haunts Saskatchewan observers by its infrequent and unexpected appearances.

Jack Lane of Brandon submitted a number of excellent cards with information on incubation periods on a number of species. Undoubtedly the highlight of his year is the observations he made on the nesting of the Yellow Rail. Three nests of this species were located and observations made on one nest from the laying of the first egg until the nest was vacated by the downy young. Lane noted the incubation period of the Yellow Rail as 13 days plus a few hours. A significant contribution indeed. The complete report appears in his article "Nesting of the Yellow Rail in Southwestern Manitoba" in the Canadian Field-Naturalist, 76: 189-191, Oct.-Dec., 1962.

G. J. Smith of Winnipeg submitted a number of excellent cards including observations of the nesting of the Grasshopper Sparrow: another first for the Prairie Nest Records Scheme.

Speaking of firsts, almost everything Ernie Kuyt records is new. To date he has submitted reports on 42 species nesting in the Northwest Territories. He is a biologist with the Canadian Wildlife Service. With headquarters at Yellow Knife and working in the Thelon area, he has recorded nesting of such species as Willow Ptarmigan, Oldsquaw, Arctic Tern, and Harris' Sparrow. His cards are sprinkled with bits of information such as "the Tree Sparrow's nest is frequently heavily lined with ptarmigan down and muskox wool."

I was fortunate to observe two bobtail Dipper chicks begging food from their mother and to observe the first Saskatchewan Sandhill Crane nest reported to the Prairie Nest Records Scheme. The Dipper observations were made in Alberta; the crane nest north of Prince Albert. I am sure that the Sandhill Crane nests in Saskatchewan every year, but it had not previously been reported to the Nest Records Scheme. This is only one of the number of relatively common birds that are presumed or known to nest in the area covered by the Scheme, but for which our files have no records. 'This list includes such species as the Gray Jay, the Olive-sided Flycatcher, the Caspian Tern, and the Common Merganser. Nest-records for Saskatchewan for the Green-winged Teal and the Rubythroated Hummingbird have not yet been submitted to this Scheme. Yet, we all know they do nest here. The point I am trying to make is that it is just as important to record information on the common nester as it is to report on the rare or unusual. The recording of information is more important than we often think. In a few years, memories dim and the information is lost forever. Filling out a nest record card takes only a minute or two. The information on the card is valuable and is always available. The records are filed in the Saskatchewan Museum of Natural History, and are available to any responsible person.

The 1963 nesting season is rapidly approaching. You are encouraged to observe and record your observations on birds nesting in your area. Nest record cards may be obtained by writing to the Prairie Nest Records Scheme, c/o The Saskatchewan Museum of Natural History, Regina, Saskatchewan. Please indicate the number of cards required. The 1962 contributors will receive cards automatically.

CONTRIBUTORS: W. Anaka, F. Brazier, D Buckle, H. H. Burns, j. D. Chandler, H. Copland E. S. Curtiss, R. Derketch, Mrs. E. A Dodd, E. and R. Fox, D. Hatch, H. Hedger H. V. Hosford, S. Houston, R. Klimack, E. Kuyt, J Lane. L. Lohr, Mamie McCowan, A C. Ninrgan, Barbara Robinson, G. J. Smith, E. f. White, Florence White, Mrs. F. Wilson, S. and R. Zazelenchuk.

SPECIES RECORDED: Common Loon (1), Red-throated Loon (1), Horned Grebe (3) Eared Grebe (1), White Pelican (1: colony of 35), Double-crested Cormcrant (3: col. 40), Great Blue Heron (1), Canada Goose (3) White-fronted Goose (3), Mallard (32), Gadwall (1), Pintail (13), Green-winged Teal (2), Bluewinged Teal (10), American Widgeon (4), Shoveler (1), Redhead (4), Canvasback (3), Greater Scaup (1), Common Goldeneye (1) Oldsquaw (2), White-winged Scoter (3) Cooper's Hawk (2), Red-tailed Hawk (10) Broad-winged Hawk (2), Swainson's Hawk (5) Rough-legged Hawk (i), Ferruginous Hawk (1), Golden Eagle (2), Marsh Hawk (1), Gyrfalcon (1). Prairie Falcon (1), Peregrine Falcon (2), Sparrow Hawk (1), Willow Ptarmigan 
(2), Gray Partridge (1), Sandhill Crane (2), Sora (1), Yellow Rail (3). American Coot (4), Semipalmated Plover (2), Killdeer (11), Common Snipe (2), Long-billed Curlew (1), Sipotted Sandpiper (2), Baird's Sandpiper (1), American Avocet (2: col. 14), Northern Phalarape (1), Herring Gull (3), Ring-billed Gull (1: col. 20), Mew Gull (2), Bonaparte's Gull (1: col. 3). Common Tern (1), Arctic Tern (9: col. 5), Black Tern (9), Rock Dove (2: large col.), Mourning Dove (10), Black-billed Cuckoo (2), Great Horned Owl (14), Burrowing Owl (2), Long-eared Owl (5), Belted-Kingfisher (1), Yellow-shafted Flicker (1), Pileated Woodpecker (1), Downy Woodpecker (3), Eastern Kingbird (9), Western Kingbird (8), Eastern Phoebe (16), Say's Phoebe (5), Least Flycatcher (2), Horned Lark (5), Tree Swallow (10), Bank Swallow (2), Barn Swallow (26). Cliff Swallow (8), Purple Martin (1: col. 42), Blue Jay (1), Black-billed Magpie (8), Common Crow (17), Dipper (1), House Wren (12), Longbilled Marsh Wren (1), Catbird (6), Brown
Throsher (4), Robin (43), Hermit Thrush (1), Gray-cheeked Thrush (2), Veery (2), Mountain Bluebird (4); Townsend's Solitaire (1), Goldencrowned Kinglet (1), Water Pipit (1), Siprague's Pipit (4), Cedar Waxwing (4), Loggerhead Shrike (2), Storling (1), Red-eyed Vireo (2), Warbling Vireo (2), Yellow Warbler, (4), MacGillivary's Warbler (1), Yellowthroat (1), House Sparrow (2), Bobolink (3), Western Meadowlark (8), Yellow-headed Blackbird (6), Red-winged Blackbird (22), Baltimore Oriole (2), Bullock's Oriole (1), Brewer's Blackbird (8), Common Grackle (3), Rose-breasted Grosbeak (3), Hoary Redpoll (5), Common Redipoll (5), American Goldfinch (2), Savannah Sparrow (3), Grasshopper Sparrow (1), Baird's Sparrow (1) Sharp-tailed Sparrow (1), Vesper Sparrow (15), Tree Sparrow (1), Chipping Sparrow (4), Clay-colored Sparrow (8), Harris' Sparrow (3), White-crowned Sparrow (1), Lincoln's Sparrow (1), Song Sparrow (5), McCown's Longspur (1), Lapland Longspur (5), Chestnut-collared Longspur (1).

\section{Twenty-first Annual Saskatchewan Christmas Bird Count, 1962}

\section{Edited by Margaret Belcher and Dorothy R. Wade, Regina}

A new record of total species counted was made this year with 68 species reported on count day from 26 localities. Observers recruited for the count numbered 135, with Saskatoon placing the largest number in the field. Even with two guests from Indiana, the Saskatoon total of 36 did not quite reach last year's record of 37 observers from that club.

The total number of species observed in Saskatchewan during 21 years of Christmas counts now stands at 108, the Regina group having added two new species-Ross' Goose and Shoveler.

Late migrants appeared more numerous than usual, presumably owing to the continuing mild weather. Mourning Dove, Brown Creeper, Western Meadowlark, three species of blackbirds and Common Grackle, Slate-colored Junco, Tree Sparrow and Song Sparrow were all reported in one or more localities. Short-eared Owls were more common than usual, reported from 10 points. Thirteen points reported Horned Larks, which were not only present in more localities but were noted frequently in flocks as though forming part of a last wave of migrants.

Gray Partridge were counted in 14 districts, with several compilers com- menting on their numbers and the large size of the winter flocks.

In assembling these records during the absence of Mary and Stuart Houston, we have appreciated the assistance given by Lucy Murray and Douglas Wade.

BATTLEFORD, Sask. Dec. $31 ; 27$ miles by car and 5 miles on foot in $41 / 2$ hours; temp. $-20^{\circ}$; wind $\mathrm{N}$. at $20 \mathrm{mph} ; 10$ inches of snow. 14 species, 218 individuals. Ruffed Grouse, 1; Sharp-tailed Grouse, 1; Rock Dove, 17; Snowy Owl, 1; Hairy Woodpecker, 3; Downy Woodpecker, 2; Blackbilled Magpie, 5; Black-capped Chickadee, 5; Bohemian Waxwing, 52; House Sparrow, 41; Evening Grosbeak, 18; Pine Grosbeak, 16; Common Redpoll, 19; Snow Bunting, 37.-Spencer Sealy.

BLADWORTH, Sask. Dec. 27; 4 hours in the field- $11 / 2$ hours by team, $21 / 2$ hours by truck or. on foot; temp. $10^{\circ}$ to $13^{\circ}$; wind S.W. at 6-8 m.p.h.; clear; snow 6 to 8 inches, mostly in drifts. 8 species, 2195 individuals. Sharp-tailed Grouse, 15; Gray Partridge, 61; Great Horned Owl, 1; Short-eared Owl, 1; Horned Lark, 29; Black-billed Magpie, 10; House Sparrow, 78; Snow Bunting, $2000 \pm$. (Add: Golden Eagle, 2, Dec. 21, Dec. 31; Rock Dove, 8, Dec. 21; 